\title{
Can the Nile generate output, income, and employment in Egypt? A mixed multiplier analysis
}

\author{
Rehab Osman*, Emanuele Ferrari ${ }^{*}$, \\ Alfredo Mainar-Causapét ${ }^{\star \star *}$, Sofía Jiménez Calvo ${ }^{\star \star \star \star}$
}

DOI: $10.30682 / \mathrm{nm} 2101 \mathrm{a}$

JEL codes: D57, E24, O21, Q11, R11, R58

\begin{abstract}
Nile water availability is one of the major constraints for agricultural development in Egypt. This study conducts a mixed multiplier analysis, under water and land constraints, to identify the seasonal agricultural activities with high output and income multipliers. It uses a 2008/09 SAM for Egypt with a detailed representation of Nile-related production factors employed by agricultural activities across irrigation seasons. The results demonstrate the significance of addressing Nile water constraints, not only for agriculture, but also for the overall economy. Policies that enhance water productivity, particularly in the winter season, generate outstanding increases in output, income, and employment through sizable multiplier effects.
\end{abstract}

Keywords: Water availability, Irrigation efficiency, Agricultural productivity, Mixed Multiplier Analysis, Egypt.

\section{Introduction}

In 2019, the Egyptian economy grew by $5.6 \%$ compared to $4.5 \%$ in the preceding four years. Nevertheless, the long-standing issues of poverty, public deficit and unemployment seem to be unresolved; 32.5\% of Egypt 99 million citizens are poor (CAPMAS, 2019) and 60\% are classified as either poor or vulnerable. In addition, public deficit (accounting for 10\% of GDP) and the double-digit unemployment rate of $11.3 \%$ poses serious challenges to an economy with one of the fastest growing populations in the world (2\%) (WB, 2019).
Although the share of agriculture in GDP has been declining since 2000 (from 16\% to $11 \%$ in 2018) and its share in employment decreased by almost 10 percentage points in the last twenty years (Zaki et al., 2020), agriculture, forestry, and fishing remain a major sector in Egyptian economy. This labour-intensive sector absorbs $25 \%$ of the total employment and $36 \%$ of female employment in 2019. In addition, the agri-food sector is a key source of foreign currency, with food accounting for $16 \%$ of total exports (WB, 2019).

Egypt has been affected by serious issues of

\footnotetext{
* Oxford Brookes Business School, Oxford Brookes University, Oxford, United Kingdom.

** European Commission, Joint Research Centre (JRC), Seville, Spain.

*** Department of Applied Economics III, University of Seville, Seville, Spain.

**** Department of Economic Analysis, University of Zaragoza, Zaragoza, Spain.

Corresponding author: emanuele.ferrari@ec.europa.eu
} 
water scarcity and quality deterioration, which could be further exacerbated by climate change and increasing population growth. Agriculture and livestock in Egypt are highly dependent and constrained by the availability and quality of Nile water. Agricultural activities consume about $80 \%$ of the Nile water budget (Abdelhafez et al., 2020). The Nile contributes to $83 \%$ of the water budget, followed by groundwater $(11 \%)$, and non-conventional sources, i.e., recycled drainage water, treated sewage water, and desalinated seawater. Agricultural land is also constrained by the available water resources. Only 3.5\% of Egypt's total land area is irrigated, $85 \%$ of which is located in the Nile Valley and Nile Delta. Besides, 35\% of Egypt's agricultural land is affected by high salinity, especially in the (over-populated) Nile Delta, where $60 \%$ of cultivated land in the northern Delta is affected by salinity (ICARDA, 2011). Under these water scarcity conditions, Egypt follows a precise seasonal multi-cropping system in three irrigation seasons: winter (November-May), summer (May-September) and Nili, i.e., Nile floods (September to November). The main crops are wheat, berseem (an Egyptian clover used for fodder) and broad beans (in the winter season), cotton, sugar cane and rice (in the summer season), whereas maize and millet crops are cultivated in the flood season. The Egyptian seasonal irrigation system helps improve land productivity. For example, cultivating berseem in the winter improves the soil quality before the soil-demanding cotton is planted in the summer. Most crops are not region-specific, with the exceptions of sugar cane, which is mainly planted in the Nile Valley, and rice, which is planted in Nile Delta. Nile Delta, where $60 \%$ of Egypt's total population inhabits, accounts for more than $60 \%$ of the total irrigated land.

The development of the agricultural sector is threatened by water scarcity (Fuglie et al., 2020). At the same time, Egypt's livestock sector production is declining because of many technical reasons, among which are the lack of fresh drinking water and groundwater contamination (Ahmed et al., 2020). Under these circumstances, investments aiming at raising water and land productivity are crucial to guarantee a stable output increase.

Osman et al. (2016) argue that enhancing water productivity and irrigation efficiency could compensate for the shortage of water supply. Since water scarcity is the predominant issue, improving water quality is the only feasible way to enhance agricultural productivity and efficiency. Better water quality boosts income by $4 \%$ and induces increases in the production of high-value crops with a $64 \%$ increase in rice exports (Osman et al., 2019).

The USAID Feed the Future Egypt Food Security and Agribusiness Support project (2015-2020) aims at enhancing food security, income, and employment by improving water and agriculture productivity. The project's impact assessment has two twin objectives, i.e., identifying the seasonal agricultural activities with the highest potential for generating output, income, and employment, as well as leveraging the linkages between agriculture and the rest of the economy.

It is in this context that this study addresses the intriguing policy question on whether the improvement of irrigation water and agriculture productivity could generate non-agricultural output, income, and employment. The study examines multiplier effects using a Social Accounting Matrix (SAM) mixed multiplier analysis that considers supply-side constraints in agriculture. A SAM provides a consistent framework to record expenditure and income flows in the economy. In this square matrix, each agent is represented by a column and a row, where expenditures and incomes are both recorded (Pyatt, 1988; Pyatt \& Round, 1977).

While SAM multiplier analysis has long been employed for Egypt, few studies calculate output and income multipliers considering supply-side constraints, and no study focuses on multipliers for seasonal agricultural sectors to date. Ernst \& Sarabia (2014) and (2015) calculate output and employment multipliers for the construction sector. Kamal (2018) identifies manufacturing and services with high output and employment multipliers. Moursi \& Mossallamy (2010) use employment and output multipliers to estimate direct, indirect, and induced 
effects of Egypt's stimulus package 2008/09. Fayed \& Ehab (2017) examine the supply chain and linkages of the construction sector.

This study fills this gap in the literature; it identifies the seasonal agricultural activities with high output, income and employment multipliers using a SAM for Egypt 2008/09 (Osman et al., 2015b). The SAM introduces irrigation water as a distinct production factor. It provides a thorough representation of agricultural activities across irrigation seasons allowing specific supply constraints on seasonal agricultural activities. A mixed multiplier analysis under water constraint conditions assumes that agriculture output expands only with improvements in water productivity. The study simulates exogenous productivity shocks that generate increases in agricultural outputs. It measures the multiplier effects of these changes in agricultural outputs on non-agricultural output, household and government income as well as employment.

Improvements in water and agriculture productivity generate employment through direct and indirect effects. Induced employment injects (private) income into the circular flow of the economy through the consumption channel. The multiplier mechanism entails higher production, tax, and (public) income. However, for some sectors, increases in productivity and output in other sectors could generate unemployment. Therefore, it is important to unravel the sector-specific forward and backward linkages and induced employment and income effects in order to identify sectors with high multipliers. Indeed, omitting the inter-linkage between the seasonal agriculture sectors and the rest of the economy means underestimating the importance of agriculture in generating income and employment and misleading economic policy makers.

The rest of the paper is structured as follows. Section 2 describes Egypt SAM as a framework for the economy's circular flow. Section 3 in- troduces the employed mixed multiplier analysis. Section 4 discusses the results and Section 5 concludes the paper.

\section{Circular flow in the Egyptian economy}

\subsection{Social Accounting Matrix}

The analysis is conducted employing a SAM for Egypt 2008/09, which has the unique advantage of including detailed accounts for seasonal agricultural sectors (Osman et al., 2015a; $2015 b$ ), including irrigation water as a separate production factor, and detailed data on areas of cultivated land and water used in irrigation. This SAM has 102 accounts: 54 activities, 16 commodities, 19 factors, 5 institutional accounts, 4 tax instruments as well as trade margin, savings/ investment, rest of the world. In addition, the SAM is completed by physical employment data compiled in the form of an employment vector, (CAPMAS, 2010). Table 1 portrays the macro SAM for Egypt 2008/09. ${ }^{1}$

In general, a SAM provides an appropriate methodology to measure generated income and employment through backward and forward linkages in the output structure. It comprises information on production functions, and (primary and secondary) income distributions. This allows for internal variables (e.g., output, income, payments to factors) to be derived from changes in exogenous variables. As such, Leontief models are used to assess the potential impacts of changes in output structure on income distribution and job creation.

\subsection{Agricultural structure}

Agriculture is a core sector in Egypt, and its main crops are wheat, fodders, and vegetables (winter), rice, other crops, sugar cane and vegetables (summer) and year-round fruits. Production factors requirement and productivity vary significantly across seasons and crops. For

\footnotetext{
1 The validity of the input-output tables, and therefore their natural extensions, the SAMs, tends to be applicable in the medium term for economies with a fairly stable productive structure, such as Egypt. Therefore, despite using more recent data, when available, would provide a more accurate description of the Egyptian economy, the use of a 2008/09 SAM does not bias the results of the analysis.
} 
Table 1 - Macro SAM for Egypt 2008/09, billion LE*.

\begin{tabular}{|c|c|c|c|c|c|c|c|c|c|c|c|c|c|c|}
\hline & 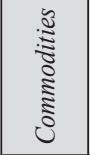 & : & 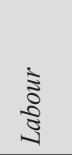 & 胥 & $\Xi$ & $\begin{array}{l}\pi \\
\vdots \\
\vdots \\
z \\
z\end{array}$ & डे & 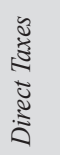 & 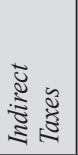 & 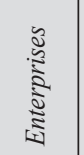 & ๘े & 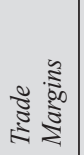 & ڤे & స్ \\
\hline Commodities & & 756.04 & & & 825.15 & 5.65 & 124.04 & & & & 207.21 & 154.72 & 258.89 & 2331.71 \\
\hline Activities & 1859.18 & & & & & & & & & & & & & 1859.18 \\
\hline Labour & & 264.14 & & & & & & & & & & & & 264.14 \\
\hline Capital & & 807.69 & & & & & & & & & & & & 807.69 \\
\hline $\mathrm{HH}$ & & & 264.14 & 268.53 & & & 62.08 & & & 291.45 & & & 23.20 & 909.40 \\
\hline N.P.I.S.H & & & & 0.20 & & & & & & 6.34 & & & 0.70 & 7.24 \\
\hline Gov & & & & 4.36 & & & & 86.30 & 57.87 & & & & 9.56 & 158.09 \\
\hline Direct Taxes & & & & & 14.00 & & & & & 72.30 & & & & 86.30 \\
\hline $\begin{array}{l}\text { Indirect } \\
\text { Taxes }\end{array}$ & 26.56 & 31.31 & & & & & & & & & & & & 57.87 \\
\hline Enterprises & & & & 476.10 & & & & & & & & & 4.28 & 480.38 \\
\hline $\mathrm{S} / \mathrm{I}$ & & & & & 55.78 & 1.59 & -28.03 & & & 110.29 & & & 67.58 & 207.21 \\
\hline $\begin{array}{l}\text { Trade } \\
\text { Margins }\end{array}$ & 154.72 & & & & & & & & & & & & & 154.72 \\
\hline ROW & 291.24 & & & 58.50 & 14.46 & & & & & & & & & 364.21 \\
\hline TOTAL & 2331.71 & 1859.18 & 264.14 & 807.69 & 909.40 & 7.24 & 158.09 & 86.30 & 57.87 & 480.38 & 207.21 & 154.72 & 364.21 & \\
\hline
\end{tabular}

Note: *LE is the abbreviation for the French caption of Egyptian pounds - livre égyptienne. Raw data are expressed in million LE. The transaction values presented in the final, extended SAM are expressed in billion LE. In the course of the SAM construction, a scaling factor of 1000 was used. Source: Osman et al., 2015 b.

example, in the summer season, when the most water-intensive crops (e.g., rice and cotton) are cultivated, more than half of the available Nile waters are consumed, Table 2.

Figure 1 depicts productivity for Nile-related production factors: Nile water, and Nile land. Overall, water has the highest productivity, particularly in the winter, and it is more pronounced in the seasonal vegetables sectors. While this pattern is applicable to winter crops, land productivity for summer sugar cane and winter fodders are the highest in comparison with the rest of crops. In the short Nili season, water productivity for rice is notable.

\section{Modelling agricultural productivity}

To conduct a rigorous analysis of multiplier effects for various productivity shocks, the conventional SAM multiplier analysis is modified to incorporate supply constraints on seasonal agricultural activities.

\subsection{Conventional multipliers}

Despite its simplicity, conventional linear multipliers analysis is useful to describe the Egyptian economy in general, and the agricultural sector and irrigation systems in particular. 
Table 2 - Egypt agricultural structure and water requirements.

\begin{tabular}{|c|c|c|c|c|c|c|c|c|c|}
\hline & \multicolumn{2}{|c|}{ Cultivated Land } & \multicolumn{2}{|c|}{ Water } & \multicolumn{3}{|c|}{ Production } & \multicolumn{2}{|c|}{ Water Requirement } \\
\hline & $\begin{array}{c}\text { Area } \\
(1000 \\
\text { feddan })\end{array}$ & $\%$ & $\begin{array}{c}\text { Water } \\
\text { Usage } \\
(\text { million } \\
\left.\mathrm{m}^{3}\right)\end{array}$ & $\%$ & $\begin{array}{l}\text { Production } \\
\text { (1000 ton) }\end{array}$ & $\%$ & $\begin{array}{l}\text { Yield } \\
\text { (ton/ } \\
\text { feddan) }\end{array}$ & $\begin{array}{c}\text { Water / } \\
\text { Land } \\
\text { Ratio }\left(\mathrm{m}^{3}\right. \\
/ \text { feddan })\end{array}$ & $\begin{array}{l}\text { Water } \\
\text { Intensity } \\
\text { (million } \\
\mathrm{m}^{3} / 1000 \\
\text { ton) }\end{array}$ \\
\hline $\begin{array}{l}\text { Winter } \\
\text { Crops }\end{array}$ & 6,734 & 43.14 & 15,892 & 33.78 & 78,349 & 54.54 & 11.63 & 2,360 & 0.20 \\
\hline Wheat & 3,133 & 20.07 & 4,556 & 9.68 & 8,493 & 5.91 & 2.71 & 1,454 & 0.54 \\
\hline Cereals & 170 & 1.09 & 199 & 0.42 & 275 & 0.19 & 1.62 & 1,171 & 0.72 \\
\hline Sugar Beet & 362 & 2.32 & 514 & 1.09 & 7,486 & 5.21 & 20.68 & 1,420 & 0.07 \\
\hline Fodders & 2,040 & 13.07 & 9,391 & 19.96 & 50,613 & 35.23 & 24.81 & 4,603 & 0.19 \\
\hline Fibbers & 16 & 0.10 & 27 & 0.06 & 40 & 0.03 & 2.50 & 1,688 & 0.68 \\
\hline $\begin{array}{l}\text { Medical \& } \\
\text { Aromatic } \\
\text { Plants }\end{array}$ & 48 & 0.31 & 61 & 0.13 & 214 & 0.15 & 4.46 & 1,271 & 0.29 \\
\hline Vegetables & 965 & 6.18 & 1,144 & 2.43 & 11,228 & 7.82 & 11.64 & 1,185 & 0.10 \\
\hline $\begin{array}{l}\text { Summer } \\
\text { Crops }\end{array}$ & 5,384 & 34.49 & 23,056 & 52.57 & 36,637 & 35.67 & 6.80 & 4,282 & 0.63 \\
\hline Rice & 1,410 & 9.03 & 10,839 & 23.04 & 5,667 & 3.95 & 4.02 & 7,687 & 1.91 \\
\hline Other Crops & 2,129 & 13.64 & 6,461 & 13.73 & 6,716 & 4.68 & 3.15 & 3,035 & 0.96 \\
\hline Sugar Cane & 326 & 2.09 & 2,766 & 5.88 & 15,765 & 10.97 & 48.36 & 8,485 & 0.18 \\
\hline Cotton & 520 & 3.33 & 1,038 & 2.21 & 853 & 0.59 & 1.64 & 1,996 & 1.22 \\
\hline Fodders & 702 & 4.50 & 1,530 & 3.25 & 7,130 & 4.96 & 10.16 & 2,179 & 0.21 \\
\hline Oily Crops & 273 & 1.75 & 361 & 0.77 & 298 & 0.21 & 1.09 & 1,322 & 1.21 \\
\hline $\begin{array}{l}\text { Medical \& } \\
\text { Aromatic } \\
\text { Plants }\end{array}$ & 24 & 0.15 & 61 & 0.13 & 208 & 0.14 & 8.67 & 2,542 & 0.29 \\
\hline Vegetables & 1,539 & 9.86 & 1,679 & 3.57 & 14,607 & 10.17 & 9.49 & 1,091 & 0.11 \\
\hline Nili Crops & 675 & 4.33 & 2,225 & 4.73 & 3,908 & 2.72 & 5.79 & 3,298 & 0.57 \\
\hline Rice & 3 & 0.02 & 1 & 0.00 & 10 & 0.01 & 3.23 & 333 & 0.10 \\
\hline Other Crops & 360 & 2.31 & 1,563 & 3.32 & 999 & 0.70 & 2.78 & 4,342 & 1.56 \\
\hline Fodders & 82 & 0.53 & 0 & 0.00 & 653 & 0.45 & 7.97 & 0 & 0.00 \\
\hline Oily Crops & 3 & 0.02 & 1 & 0.00 & 1 & 0.00 & 0.43 & 333 & 0.77 \\
\hline $\begin{array}{l}\text { Medical \& } \\
\text { Aromatic } \\
\text { Plants }\end{array}$ & 1 & 0.00 & 82 & 0.17 & 0 & 0.00 & 0.29 & 117,143 & 410.00 \\
\hline Vegetables & 226 & 1.45 & 578 & 1.23 & 2,244 & 1.56 & 9.93 & 2,558 & 0.26 \\
\hline Fruits & 1,277 & 8.18 & 4,197 & 8.92 & 10,144 & 7.06 & 7.94 & 3,287 & 0.41 \\
\hline Total & 15,609 & 100 & 47,049 & 100 & 143,645 & 100 & 9.20 & 3,014 & 0.33 \\
\hline
\end{tabular}

Note: A feddan is a non-metric measurement unit of land area equivalent to 1.037 acres, 0.420 hectares or $4,220 \mathrm{~m}^{2}$. Source: Compiled by the authors. 
Figure 1 - Productivity for Nile-related production factors.

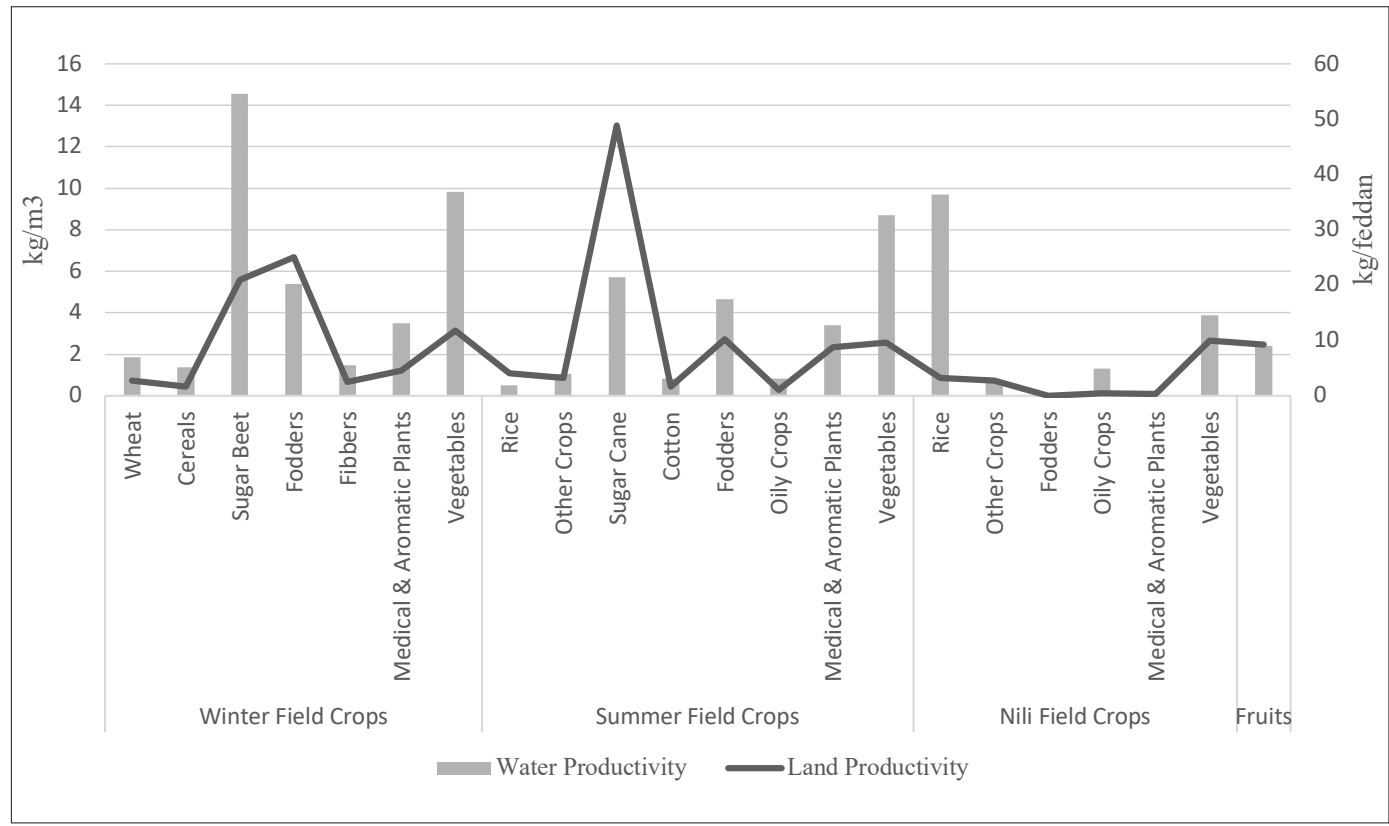

Note: Water productivity is calculated as the ratio between production (in metric tons) and water usage $\left(\right.$ million $\left.\mathrm{m}^{3}\right)$, while land productivity is calculated as the ratio between production and area (1000 feddan). Source: Compiled by the authors.

Osman et al. (2015a), following Leontief(1936), and Pyatt \& Round (1979), estimate conventional linear multipliers for the Egyptian economy,

$$
\mathbf{x}_{\mathbf{n}}=\mathbf{A}_{\mathrm{n}} \mathbf{x}_{\mathrm{n}}+\mathbf{y}_{\mathrm{n}}=\left(\mathbf{I}-\mathbf{A}_{\mathrm{n}}\right)^{-1} \mathbf{y}_{\mathrm{n}}=\mathbf{M} \mathbf{y}_{\mathrm{n}}
$$

where $\mathbf{x}_{\mathrm{n}}$ is the vector of total gross output of endogenous accounts; $\mathbf{y}_{\mathrm{n}}$ is the corresponding vector of total final demand; $\mathbf{A}_{\mathrm{n}}$ is the matrix of average expenditure propensities of endogenous accounts, whose components $a_{\mathrm{ij}}$ represent the expenditure on account $i$ for each unit of expenditure or total employment in $i ; \mathbf{y}_{\mathrm{n}}$ is the column vector that counts the total income flow received by endogenous accounts from exogenous accounts (usually total or partial final demand); and $\mathbf{M}$ is the SAM accounting multipliers matrix.

Osman et al. (2015a) identify 'other crops', namely wheat (winter), rice and 'other crops' (summer), and seasonal vegetables as the key agricultural activities in the primary sector and select 'food services' among the sectors with strong backward linkages. In addition, the study highlights the positive effects on most agricultural activities (e.g., 'accommodation and food services'), manufacturing activities, education and 'social protection'. Another noteworthy positive relationship is the estimated between 'environmental protection' and services activities.

Results derived from the conventional multiplier analysis should be taken with a grain of salt. The implicit assumption, in accounting multipliers, that all productive sectors are demand-driven with a perfectly elastic supply is not valid for all sectors. This assumption is particularly unrealistic for agriculture in developing countries, where manifest supply constraints are imposed (Rich et al., 1997; Haggblade et al., 1991; Subramanian \& Sadoulet, 1990; Lewis \& Thorbecke, 1992). Ignoring these constraints leads to overestimated multiplier results (Haggblade et al., 1989; Lewis \& Thorbecke, 1992).

A mixed multiplier analysis relaxes this assumption and specifies activities with supply constraints, where the output could only expand with external improvements in production 
factors's productivity. This allows for rigorous multiplier analysis and robust estimation of the impacts on the rest of the economy.

\subsection{Mixed multipliers model}

Two fundamental reasons justify the use of mixed multplier analysis. Firstly, it provides accurate estimates of the impacts generated by hypothetical demand-driven shocks in the non-constrained sectors. Secondly, it measures the effects of external shocks in sectors with constrained outputs, through improvements of productivity or more efficient use of the available production factors. As such, a mixed multiplier analysis evaluates the effects of an exogenous increase in agricultural output, induced by a more efficient use of water and higher productivity, on the Egyptian economy through backward and forward linkages.

A mixed multiplier analysis, firstly developed by Miller \& Blair (1985) in the context of input-output (I-O) models, extends the analysis to the SAM-Leontief models (Subramanian \& Sadoulet, 1990; Lewis \& Thorbecke, 1992). The results obtained by the last two studies are then generalized by Parikh \& Thorbecke (1996). McDonald \& Punt (2002) conduct a mixed multiplier analysis of the implications of trade liberalisation for agriculture in South Africa under the supply constraints condition of limited land.

The mixed multiplier model identifies two types of sectors: unconstrained sectors, which respond to changes in final demand, and constrained sectors with a fixed output which, consequently, cannot freely respond to increases in final demand. In our analysis, agriculture, Nile water, and land accounts have fixed output but are still considered endogenous. The difference as opposed to traditional multipliers is that, for constrained sectors, it is not final demand that is fixed and can be exogenously modified to influence the output but, on the contrary, the output is fixed and its exogenous alteration affects the final demand of these sectors and the output of the rest of the activities.

Nile water and land supply in different irrigation seasons are specified to be fixed at their baseline levels. Agriculture output is exogenous and could only increase via external shocks in productivity. The model is presented as follows,

$\left[\begin{array}{c}\mathbf{x}_{\mathrm{nc}} \\ \mathbf{y}_{\mathrm{c}}\end{array}\right]=\left[\begin{array}{cc}\left(\mathbf{I}-\mathbf{A}_{\mathrm{nc}}\right) & \mathbf{0} \\ -\mathbf{R} & -\mathbf{I}\end{array}\right]^{-1}\left[\begin{array}{cc}\mathbf{I} & \mathbf{Q} \\ \mathbf{0} & -\left(\mathbf{I}-\mathbf{A}_{\mathrm{c}}\right)\end{array}\right]\left[\begin{array}{c}\mathbf{y}_{\mathrm{nc}} \\ \mathbf{x}_{\mathrm{c}}\end{array}\right]=\mathbf{M}_{\mathrm{m}}\left[\begin{array}{c}\mathbf{y}_{\mathrm{nc}} \\ \mathbf{x}_{\mathrm{c}}\end{array}\right]$

where

$$
\left[\begin{array}{cc}
\mathbf{A}_{\mathrm{nc}} & \mathbf{Q} \\
\mathbf{R} & \mathbf{A}_{\mathrm{c}}
\end{array}\right]=\left[\begin{array}{cc}
\mathbf{Z}_{\mathrm{nc}, \mathrm{nc}} & \mathbf{Z}_{\mathrm{nc}, \mathrm{c}} \\
\mathbf{Z}_{\mathrm{c}, \mathrm{nc}} & \mathbf{Z}_{\mathrm{c}, \mathrm{c}}
\end{array}\right]\left[\begin{array}{cc}
\hat{\mathrm{x}}_{\mathrm{nc}}^{-1} & 0 \\
0 & \widehat{\mathbf{X}}_{\mathrm{c}}^{-1}
\end{array}\right]
$$

here, using the subscript $c$ (constrained) to distinguish accounts with exogenous output than not constrained ( $n c$ ) accounts; $\mathbf{x}$ and $\boldsymbol{y}$ the output/ availability and the income vectors respectively; and $\mathbf{z}$ is the submatrix of endogenous accounts.

Following Pyatt and Round (1979), and Mainar-Causapé et al. (2018), public sector, savings and investment, and the rest of the world are the exogenous accounts.

Thus, $\mathbf{M}_{\mathbf{m}}$ reflects the effect of the existing restrictions in agriculture output and Nile water and land factors. This restriction entails a logical decrease in the values of the accounting multipliers calculated for the remaining activities, commodities, or factors.

Since the main issue to analyse is the effect of shocks on the output of agricultural activities, only the corresponding values for these agricultural activities in columns will be taken from the entire $\mathbf{M}_{\mathbf{m}}$ matrix. The values in the rows of the rest of the activities give the effect on the output of non-agricultural activities, while the values in the rows of households and government show the effect on the income of these institutions.

To obtain employment multipliers, a vector e that contains the ratios of employment per output value is required. The diagonal version of $\mathbf{e}$, matrix $\mathbf{E}$, is multiplied by the sub-matrix of $\mathbf{M}_{\mathrm{m}}$ which incorporates the rows corresponding to the productive accounts (and agriculture accounts as columns), called $\mathbf{M}_{\mathrm{m}}{ }^{*}$. The expression of the employment multiplier matrix, $\mathbf{M}_{\mathbf{m}}(\mathbf{e})$, is given as:

$$
\mathbf{M}_{\mathrm{m}}(\mathbf{e})=\mathrm{E} \mathrm{M}_{\mathrm{m}} *
$$

Each element $i, j$ in $\mathbf{M}_{\mathbf{m}}(\mathbf{e})$ indicates the increment of the employment of the account $i$ generated by an unitary increase in output of account $j$. 


\subsection{External shocks}

As previously mentioned, agriculture in Egypt is constrained by limited water resources and a fully exploited land. Under these conditions, agricultural output can only expand with exogenous improvements in Nile water and/or land productivity and efficiency. Indeed, Gohar \& Ward (2011) argue that a more efficient allocation of Nile water induces expansions in agriculture output and generates a $28 \%$ increase in national farm income.

Our analysis examines how an increase in agricultural production could affect other sectoral outputs, employment, and household income. Based on the agricultural structure (Sub-section 2.2), it quantifies the impacts of an increase in the agricultural output, induced by exogenous improvements in the use of Nile water and land, on non-primary sectors' output, employment, and household income.

The improvements in irrigation efficiency and productivity in this model are exogenous, given the specific characteristics of SAM models. The interesting question related to how irrigation efficiency and productivity could be improved falls beyond the scope of this research. An increased efficiency cannot be achieved without increasing investment and expenditure in research and development. These costs will have wider economic effects depending on the amount needed to achieve the simulated productivity shocks, the financing of the costs and the secondary effects of these expenditures on the agricultural sector. The lack of the cost-related data might produce a slight overestimation of the results. Previous analyses conducted for Egypt (Osman et al., 2019) demonstrate that improving irrigation water quality has strong positive economy-wide impacts which compensate for the costs associated to the water quality improvement projects. With noticeable expansions in high-value crops (i.e., fruits, seasonal vegetables, and rice), income increases by $4 \%$.

\section{Mixed multipliers results}

\subsection{Output and income multipliers}

The multiplier values (Table 3 ) refer to changes in non-agricultural outputs, as well as household and government income, in response to an exogenous unitary increase in crop output across the seasons. Sectors with backward and forwards linkages greater than one are the key sectors in the economy (Chenery \& Watanabe, 1958; Rasmussen, 1956). Sectors with strong backward linkages have a high demand for other sectors' output, and, as a consequence, they stimulate those backward sectors.

Almost all seasonal crops have strong multiplier effects on non-agriculture output and, to a lesser extent, on household income. This is particularly true for cotton, rice, fodders, vegetables, and fruits. Multiplier effects on government tax revenue are trivial, as seasonal crops display multiplier values lower than one.

Cotton (the Egyptian 'white gold') has a strong forward linkage with the textile industry, the manufacturing sector, that is a main source of farmers' income, and export revenues. The textile industry contributes to $3 \%$ of GDP, absorbs around one-third of the industrial labour force, and accounts for $15 \%$ of non-petroleum exports.

Rice has also great importance for the country's output and income structures and is a major export crop. It accounts for more than $6 \%$ of the agricultural output; a substantial share of rice production is exported, contributing to more than $10 \%$ of the total agricultural exports.

Vegetables and fruits are crucial sectors for the Egyptian economy, comprising 26\% and 7\% of agricultural GDP respectively. Fruits contribute virtually to half of the agricultural exports. In addition, processed and preserved vegetables and fruits are among the largest manufacturing industries in Egypt. These explain the significant direct and indirect effects of vegetables and fruits on the outputs of other sectors and the economy-wide income.

These results are compatible with findings by Siam (2013). The author uses 2009/10 SAM for Egypt and finds high backward linkages for crop and livestock production and high forward linkages for trade and services, social services, agro-vegetal and oil \& extracts, while food industrial production exhibits high backward and forward linkages.

Figure 2 depicts changes in output (including agricultural and non-agricultural sectors) 
Table 3 - Output and income multipliers.

\begin{tabular}{|c|c|c|c|}
\hline & $\begin{array}{l}\text { Output non- } \\
\text { agricultural }\end{array}$ & HH income & Govt. tax revenue \\
\hline Winter Field Crops & 1.10 & 1.00 & 0.15 \\
\hline Wheat & 1.09 & 0.93 & 0.13 \\
\hline Cereals & 1.12 & 0.86 & 0.11 \\
\hline Sugar Beet & 1.02 & 0.95 & 0.13 \\
\hline Fodders & 1.10 & 1.06 & 0.16 \\
\hline Fibbers & 1.08 & 0.97 & 0.13 \\
\hline Medical \& Aromatic Plants & 1.10 & 0.99 & 0.14 \\
\hline Vegetables & 1.13 & 1.05 & 0.16 \\
\hline Summer Field Crops & 1.05 & 0.94 & 0.13 \\
\hline Rice & 0.95 & 0.86 & 0.12 \\
\hline Other Crops & 1.02 & 0.89 & 0.11 \\
\hline Sugar Cane & 1.05 & 0.95 & 0.14 \\
\hline Cotton & 1.21 & 1.06 & 0.14 \\
\hline Fodders & 1.12 & 1.06 & 0.16 \\
\hline Oily Crops & 1.05 & 0.97 & 0.13 \\
\hline Medical \& Aromatic Plants & 1.09 & 0.98 & 0.14 \\
\hline Vegetables & 1.08 & 0.98 & 0.14 \\
\hline Nili Field Crops & 1.08 & 0.97 & 0.13 \\
\hline Rice & 1.13 & 1.04 & 0.13 \\
\hline Other Crops & 1.04 & 0.91 & 0.12 \\
\hline Fodders & 1.15 & 1.08 & 0.16 \\
\hline Oily Crops & 0.95 & 0.85 & 0.11 \\
\hline Medical \& Aromatic Plants & 1.03 & 0.91 & 0.13 \\
\hline Vegetables & 1.10 & 1.01 & 0.15 \\
\hline Fruits & 1.12 & 1.04 & 0.14 \\
\hline
\end{tabular}

Source: Compiled by the authors.

as well as household and government income induced by a $10 \%$ increase in crop production. The latter is generated by an improvement in water productivity. Results show a systematic pattern across all seasons, when changes are in descending order, starting with the highest changes in total output followed by changes in household and government income. Productiv- ity improvements in winter field crops (particularly wheat, fodders and vegetables) show the biggest changes (Table 4). These three winter crops are of great importance for expanding output and generating household and government income. In the summer, vegetables and, to a lesser extent, other crops and rice generate notable changes. 
Figure 2 - Total output, household and government income (\% change).

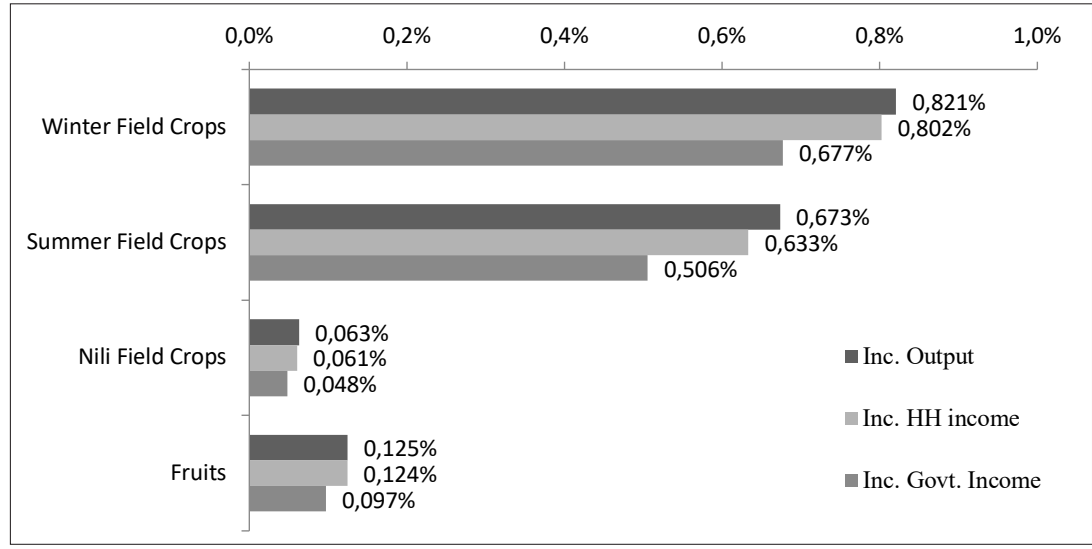

Source: Compiled by the authors.

Table 4 - Total output, household and government income (\% change).

\begin{tabular}{|l|c|c|c|}
\hline & Inc. Output & Inc. HH income & Inc. Govt. Income \\
\hline Winter Field Crops & $\mathbf{0 . 8 2 \%}$ & $\mathbf{0 . 8 0 \%}$ & $\mathbf{0 . 6 8 \%}$ \\
\hline Wheat & $0.29 \%$ & $0.26 \%$ & $0.21 \%$ \\
\hline Cereals & $0.01 \%$ & $0.01 \%$ & $0.01 \%$ \\
\hline Sugar Beet & $0.03 \%$ & $0.03 \%$ & $0.02 \%$ \\
\hline Fodders & $0.26 \%$ & $0.27 \%$ & $0.24 \%$ \\
\hline Fibbers & $0.00 \%$ & $0.00 \%$ & $0.00 \%$ \\
\hline Medical \& Aromatic Plants & $0.00 \%$ & $0.00 \%$ & $0.00 \%$ \\
\hline Vegetables & $0.22 \%$ & $0.23 \%$ & $0.19 \%$ \\
\hline Summer Field Crops & $\mathbf{0 . 6 7 \%}$ & $\mathbf{0 . 6 3 \%}$ & $\mathbf{0 . 5 1 \%}$ \\
\hline Rice & $0.13 \%$ & $0.11 \%$ & $0.09 \%$ \\
\hline Other Crops & $0.15 \%$ & $0.14 \%$ & $0.10 \%$ \\
\hline Sugar Cane & $0.06 \%$ & $0.05 \%$ & $0.05 \%$ \\
\hline Cotton & $0.05 \%$ & $0.05 \%$ & $0.04 \%$ \\
\hline Fodders & $0.04 \%$ & $0.04 \%$ & $0.03 \%$ \\
\hline Oily Crops & $0.02 \%$ & $0.02 \%$ & $0.02 \%$ \\
\hline Medical \& Aromatic Plants & $0.00 \%$ & $0.00 \%$ & $0.00 \%$ \\
\hline Vegetables & $0.23 \%$ & $0.22 \%$ & $0.18 \%$ \\
\hline Nili Field Crops & $\mathbf{0 . 0 6 \%}$ & $\mathbf{0 . 0 6 \%}$ & $\mathbf{0 . 0 5 \%}$ \\
\hline Rice & $0.00 \%$ & $0.00 \%$ & $0.00 \%$ \\
\hline Other Crops & $0.02 \%$ & $0.02 \%$ & $0.02 \%$ \\
\hline Fodders & $0.00 \%$ & $0.00 \%$ & $0.00 \%$ \\
\hline Oily Crops & $0.00 \%$ & $0.00 \%$ & $0.00 \%$ \\
\hline Medical \& Aromatic Plants & $0.00 \%$ & $0.00 \%$ & $0.00 \%$ \\
\hline Vegetables & $0.03 \%$ & $0.03 \%$ & $0.03 \%$ \\
\hline Fruits & $\mathbf{0 . 1 2 \%}$ & $\mathbf{0 . 1 2 \%} \%$ & $\mathbf{0 . 1 0 \%}$ \\
\hline
\end{tabular}

Source: Compiled by the authors. 


\subsection{Employment multipliers}

Agricultural employment multipliers are higher than in non-agricultural multipliers (Table 5). Agricultural employment multipliers do not vary significantly since the same employment is conducted uniformly across crops. Nevertheless, various backward and forward linkages with industries generate slightly different multipliers.

The highest employment multipliers are generated in cotton, cereals, fodders, fruits and vegetables. As explained before, cotton, with the forward-linked textile industry, provides employment to several million Egyptian workers.
In addition, cereals, fruits, and vegetables have strong forward linkages with the food products and beverage production sector, which absorbs $25 \%$ of the total manufacturing employment, making it the largest employer within the manufacturing sectors.

Table 5 shows the number of jobs generated by an increase of $10 \%$ in agricultural output associated to an exogenous increase of water productivity. Winter field crops generate the highest number of jobs. This result is mainly due to wheat, fodders, and vegetables. In addition, some of the summer field crops achieve high values of generated jobs,

Table 5 - Number of generated jobs (employees).

\begin{tabular}{|c|c|c|c|}
\hline & Non-agricultural & Agricultural & Total \\
\hline Winter Field Crops & 65,042 & 262,041 & 327,083 \\
\hline Wheat & 22,549 & 91,933 & 114,481 \\
\hline Cereals & 856 & 3,381 & 4,236 \\
\hline Sugar Beet & 2,412 & 10,584 & 12,996 \\
\hline Fodders & 21,089 & 84,075 & 105,165 \\
\hline Fibbers & 118 & 485 & 603 \\
\hline Medical \& Aromatic Plants & 348 & 1,400 & 1,748 \\
\hline Vegetables & 17,670 & 70,183 & 87,853 \\
\hline Summer Field Crops & 51,314 & 220,613 & $\mathbf{2 7 1 , 9 2 7}$ \\
\hline Rice & 9,001 & 43,116 & 52,117 \\
\hline Other Crops & 11,095 & 49,554 & 60,649 \\
\hline Sugar Cane & 4,410 & 18,929 & 23,339 \\
\hline Cotton & 4,252 & 15,590 & 19,841 \\
\hline Fodders & 3,069 & 12,100 & 15,169 \\
\hline Oily Crops & 1,816 & 7,758 & 9,574 \\
\hline Medical \& Aromatic Plants & 135 & 547 & 681 \\
\hline Vegetables & 17,536 & 73,020 & 90,556 \\
\hline Nili Field Crops & 4,868 & 20,381 & 25,249 \\
\hline Rice & 46 & 185 & 231 \\
\hline Other Crops & 1,790 & 7,856 & 9,646 \\
\hline Fodders & 374 & 1,438 & 1,812 \\
\hline Oily Crops & 8 & 40 & 49 \\
\hline Medical \& Aromatic Plants & 3 & 12 & 15 \\
\hline Vegetables & 2,646 & 10,849 & 13,496 \\
\hline Fruits & 9,891 & 39,401 & 49,292 \\
\hline Total & 131,115 & 542,436 & 673,551 \\
\hline
\end{tabular}

Source: Compiled by the authors. 
Figure 3 - Employment (\% change).

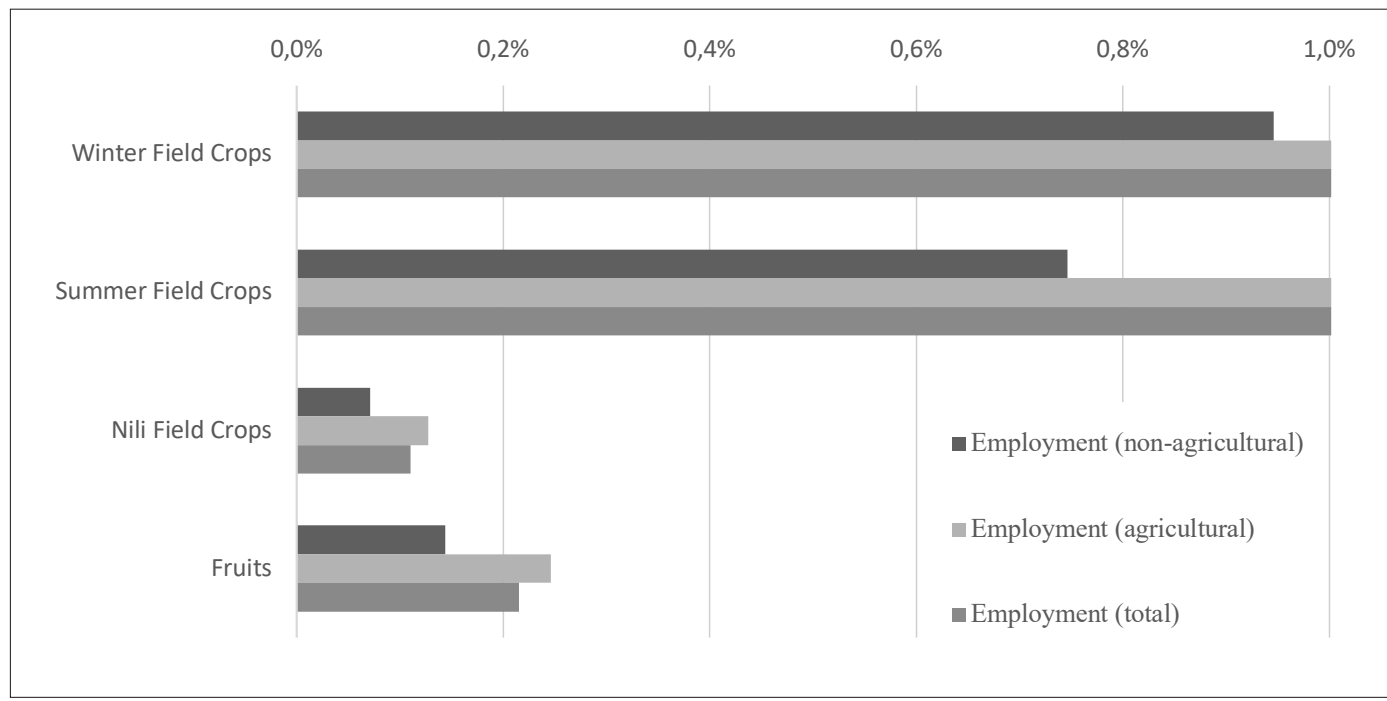

Source: Compiled by the authors.

except in the case of oily crops and medical and aromatic plants. The sectors with the highest direct increases in employment are also those with the highest forward and backward linkages in other non-agricultural industries.

Figure 3 shows changes in employment induced by a $10 \%$ increase in water productivity. Improving productivity for winter and summer crops generates an increase in employment, mainly in the agriculture sector, higher than $1 \%$. Sectoral results show that wheat, fodders (in the winter) vegetables, other crops, and rice (in the summer) are the most important sectors to generate employment.

\subsection{Results robustness}

The correlations between water productivity and the generated changes in total output (left) and in employment (right) (Figure 4) help examine the robustness of the results.

Water productivity is positively correlated with total output and employment. In other words, the more productive is water, the higher are the increases in total output and in employment. This implies that improving water productivity is important not only for increasing the agricultural output, but also for the overall econ- omy to expand through backward and forward linkages. In addition, improving water productivity helps in reducing unemployment in Egypt.

\section{Conclusions and discussions}

Egypt faces a shortage of freshwater resources; the problem is predicted to significantly aggravate with the country's rapid population growth rate and under the adverse climate change issues. With limited availability of Nile water and land, the agricultural output will increase only by improving productivity and promoting more efficient use of these scarce resources. Good news is that by investing in infrastructures for water and land, and by enhancing agriculture productivity the country may produce sizable profits not only within the sector, but also throughout the rest of the economy via several multiplier effects.

The paper conducts a mixed multiplier analysis for the Egyptian agriculture sector. It uses 2008/09 SAM extended with detailed accounts of seasonal agricultural sectors showing constrained water and land supply. By simulating improvements in water and land productivity, output, income, and employment multipliers are calculated. 
Figure 4 - Correlation lines.

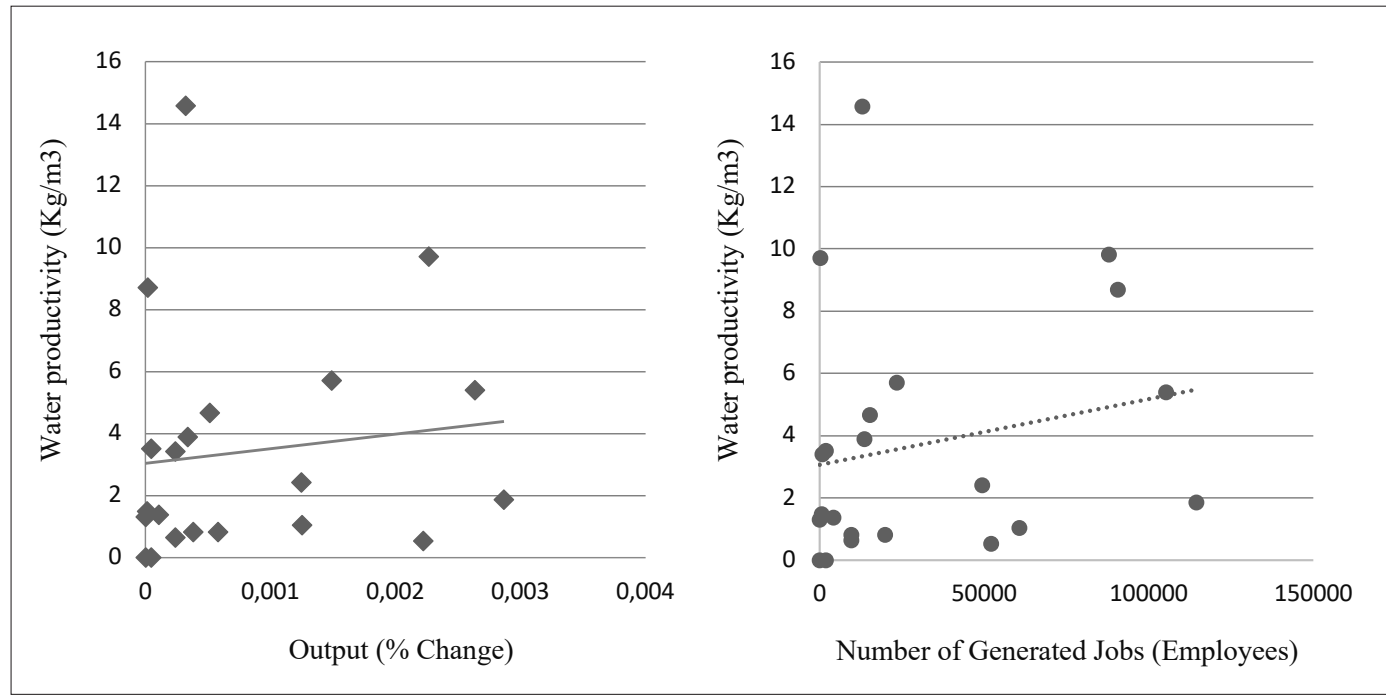

Source: Compiled by the authors.

The results show that the highest changes in output, income, and employment occur in winter field crops. This is particularly the case for wheat, fodders, and vegetables. In addition, rice, the main summer crop, generates significant multiplier effects. A similar seasonal pattern is depicted: where the highest changes occur in sectoral outputs with descending changes in household and government income.

The Egyptian economy is under continuous strain with structural problems in the labour market. These include high unemployment rates, an inefficiently large public sector with excessive employment, a sizable informal unemployment, and mismatches between demanded skills and labour supply. Our analysis measures employment multipliers and numbers of generated jobs under a $10 \%$ increase in agricultural output. Agricultural employment multipliers are not only higher than their non-agricultural counterparts, but they also have remarkable direct and indirect impacts on the overall economy; as a matter of fact, improving Nile water and land productivity by only $10 \%$ could generate jobs for virtually 674 thousand Egyptians.

Most of the policies based on agricultural productivity analysis have focused on the sec- tor's direct contribution to the Egyptian economy. By explicitly quantifying the backward and forward linkages for various seasonal crops, our paper provides new insights about the magnitude of the sector's direct, indirect, and induced effects on output, income, and employment. Our results demonstrate the significance and importance of policies that aim at improving Nile water and land productivity, enhancing irrigation efficiency, and optimizing the use of agricultural natural resources. Even though the costs of the improvement of irrigation efficiency and productivity are not measured specifically in this research, agriculture shows great potential for the rest of the Egyptian economy and could generate noteworthy socio-economic effects, which will compensate for the costs. Agricultural productivity-led policies generate economy-wide output expansions, which create more jobs and income. Hence, the sector could potentially be a key driving force of Egypt's sustainable development strategy. This result could be achieved by increasing public investments in agricultural research and expansion so as to develop new technologies and increase the total agriculture productivity (see also Fuglie et al., 2020). 


\section{Acknowledgements}

The authors would like to thank the two anonymous reviewers for their valuable remarks and comments.

\section{Disclaimer}

The views expressed in this paper are the sole responsibility of the authors and do not necessarily reflect those of the European Commission.

\section{References}

Abdelhafez A.A., Metwalley S.M., Abbas H.H., 2020. Irrigation: Water Resources, Types and Common Problems in Egypt. In: Omran ES., Negm A.M. (eds.), Technological and Modern Irrigation Environment in Egypt. Springer Water. Cham: Springer, pp. 15-34. https://doi.org/10.1007/978-3-030-30375-4_2.

Ahmed O., Abdel-Salam S., Rungsuriyawiboon S., 2020. Measuring the economic performance of mixed crop-livestock farming systems in Egypt: A non-parametric DEA approach. New Medit, 19(2): 133-145.

CAPMAS, 2010. Egypt Statistical Yearbook 2010. Cairo: Central Agency for Public Mobilization and Statistics of Egypt.

CAPMAS, 2019. Main Indicators of Household Income, Expenditure, and Consumption Survey, October 2017-September 2018. Cairo: Central Agency for Public Mobilisation and Statistics.

Chenery H.B., Watanabe T., 1958. International Comparisons of the Structure of Production. Econometrica, 26(4): 487-521.

Ernst C., Sarabia M., 2014. The Employment Dimension of Construction: A Closed Input-Output Analysis. Coyuntura Economica: Investigacion Economica y Social, XLIV(1): 239-288.

Ernst C., Sarabia M., 2015. Urgent Plan to Activate the Egyptian Economy: An Employment. Employment Working Paper, 176. Geneva: International Labour Office, Employment Policy Department.

Fayed M., Ehab M., 2017. Construction Supply Chain, Inter-Sectoral Linkages and Contributions to Economic Growth: The Case of Egypt. Review of Economics \& Political Science, 2(2).

Fuglie K., Dhehibi B., El Shahat A., Aw-Hassan A., 2020. Water, Policy and Productivity in Egyptian Agriculture. Working Paper, February, 2020. Beirut: RALSP-ICARDA. https://mel.cgiar.org/reporting/download/hash/0644fec67f611eb89a4c482b01966035.

Gohar A.A., Ward F.A., 2011. Gains from Improved
Irrigation Water Use Efficiency in Egypt. International Journal of Water Resources Development, 27(4): 737-758.

Haggblade S., Hammer J., Hazell P., 1991. Modeling Agricultural Growth Multipliers. American Journal of Agricultural Economics, 73: 361-374.

Haggblade S., Hazel P., Brown J., 1989. Farm Nonfarm Linkages in Rural Sub-Saharan Africa. World Development, 17: 1173-1201.

ICARDA (International Center for Agricultural Research in the Dry Areas), 2011. Water and Agriculture in Egypt. Technical Paper based on the Egypt-Australia-ICARDA Workshop on On-farm Water-use Efficiency. Beirut: ICARDA.

Kamal A.M., 2018. Which Sectors Drive Egypt's Growth and Employment? Economics, 6(2): 57-70.

Leontief W., 1936. Quantitative Input-output Relations in the Economic System of the United States. Review of Economics and Statistics, 18(3): 105-125.

Lewis B.D., Thorbecke E., 1992. District-Level Economic Linkages in Kenya: Evidence Based on a Small Regional Social Accounting Matrix. World Development, 20(6): 881-897.

Mainar-Causapé A., Ferrari E., McDonald S., 2018. Social Accounting Matrices: Basic Aspects and Main Steps for Estimation. JRC Technical Reports. Luxembourg: Publications Office of the European Union.

McDonald S., Punt C., 2002. Supply Constraints, Export Opportunities and Agriculture in the Western Cape of South Africa. Journal of Studies in Economics and Econometrics, 26(1): 1-18.

Miller R.E., Blair P.D., 1985. Input-Output Analysis. New Jersey: Prentice-Hall.

Moursi T.A., Mossallamy M.E., 2010. Measuring the Impact of the Egyptian Fiscal Stimulus Package 2008/2009. Cairo: ILO.

Osman R., Ferrari E., Mainar-Causapé A.J., McDonald S., 2015a. An extended SAM for Egypt (2008/09): Conventional and Mixed Multiplier Analyses. The 6th Spanish Conference on Input-Output Analysis. Barcelona: Input-Output Analysis Society (SHAIO).

Osman R., Ferrari E., McDonald S., 2015b. Constructing a SAM for Egypt (2008/09): Introducing Water and Irrigation Seasonality. Journal of Development and Economic Policies, 17(1): 5-29.

Osman R., Ferrari E., McDonald S., 2016. Water Scarcity and Irrigation Efficiency in Egypt. Water Economics and Policy, 2(4): 1-28.

Osman R., Ferrari E., McDonald S., 2019. Is Improving Nile Water Quality 'Fruitful'? Ecological Economics, 161: 20-31.

Parikh A., Thorbecke E., 1996. Impact of Rural Indus- 
trialization on Village Life and Economy: A Social Accounting Matrix. Economic Development and Cultural Change, 44(2): 351-377.

Pyatt G., 1988. A SAM Approach to Modeling. Journal of Policy Modeling, 10(3): 327-352.

Pyatt G., Round J.I., 1977. Social Accounting Matrices for Development Planning. Review of Income and Wealth, 23(4): 339-364.

Pyatt G., Round J.I., 1979. Accounting and Fixed Price Multipliers in a Social Accounting Matrix Framework. Economic Journal, 89(356): 850-873.

Rasmussen P.N., 1956. Studies in Inter-Sectoral Relations. Amsterdam: North-Holland P.C.

Rich K.M., Winter-Nelson A.E., Nelson G.C., 1997. Political Feasibility of Structural Adjustment in Africa: An Application of SAM Mixed Multipliers. World Development, 25(12): 2105-2114.

Siam G.M., 2013. Country Case study: Egypt. In: Boulanger P., Kavallari A., Cardenete M.A., Rau M.-L. (eds.), Economic Growth in the Euro-Med
Area through Trade Integration: Focus on Agriculture and Food, North Africa case studies: Egypt, Morocco, Tunisia. Luxembourg: Publications Office of the European Union, pp. 9-31.

Subramanian S., Sadoulet E., 1990. The Transmission of Production Fluctuations and Technical Change in a Village Economy: A Social Accounting Matrix Approach. Economic Development and Cultural Change, 39(1): 131-173.

WB (World Bank), 2019. Macro Poverty Outlook: Country-by-country Analysis and Projections for the Developing World. Middle East and North Africa. Washington DC: World Bank Publications.

WB (World Bank), 2019. World Development Indicators Database. Retrieved 11 9, 2019, from https:// databank.worldbank.org/.

Zaki C., Alshyab N., Seleem N., 2020. Employment intensity and sectoral output growth: a comparative analysis of Egyptian and Jordanian economies. New Medit, 19(1): 35-54. 